\title{
The Natives Emigrating in the Cultural Community of Thailand from the Tourism Adaptation
}

\author{
Supoj Prompayuk ${ }^{1^{*}}$, Panayu Chairatananonda ${ }^{2}$ \\ 1 Faculty of Industrial Technology, \\ Phranakhon Rajabhat University (PNRU), Thailand \\ ${ }^{2}$ Faculty of Architecture, \\ King Mongkut's Institute of Technology Ladkrabang (KMITL), Thailand \\ supojter@gmail.com
}

\begin{abstract}
Cultural heritages communities in Thailand were mostly adapted into a tourist attraction. The objective of this study was to investigate the occurrences of the natives in the central region of Thailand emigrating from their aboriginal communities from this cause. Since This adaptation successfully generates more income to the community, it also attracts outsiders to come in and exploit the better economic situation but pushes the natives away. Thus, the uniqueness and attractiveness of the local way of life and culture starts to disappear and will lose them almost entirely, such as the occurrences at Amphawa, Samchuk and Chiang Khan community.

Keywords: Cultural community; Heritage conservation; Tourism; Conservation in developing country

eISSN 2398-4279 @ 2018. The Authors. Published for AMER ABRA cE-Bs by e-International Publishing House, Ltd., UK. This is an open access article under the CC BY-NC-ND license (http://creativecommons.org/licenses/by$n c-n d / 4.0 /$ ). Peer-review under responsibility of AMER (Association of Malaysian Environment-Behaviour Researchers), ABRA (Association of Behavioural Researchers on Asians) and CE-Bs (Centre for EnvironmentBehaviour Studies), Faculty of Architecture, Planning \& Surveying, Universiti Teknologi MARA, Malaysia.
\end{abstract}

DOI: https://doi.org/10.21834/ajqol.v3i12.153 


\subsection{Introduction}

At present, various local communities that had been revived both in physical aspect and economic and social aspect became famous tourist attractions (Chukaew, 2014). They were known as old markets, floating markets or a hundred year markets and became a weekend destination for Thais and foreigners (Pimolsathein, 2012). Currently, the conservation of communities with historical and cultural significance targets mainly to protect or preserve buildings and architecture or physical surroundings, and this kind of maintenance need the sizable fund much more than the community could afford. One of the solution in raising fund for the conservation is to support and encourage the community with historical or cultural value and significance to develop itself to be the site for tourism. By using the uniqueness of their cultural identity as a selling point, these communities turn to be a famous tourist attraction. But the conservation and protection of the cultural heritage for the future is crucial to promoting and supporting the study of history, arts, aesthetic, ethnography and anthropology and could help the local and national economy from the tourism income. (Sanglimsuwan and Sanglimsuwan, 2012) The community conservation in Thailand mostly targets for promoting the tourism which believed that could improve the local economic from the recession (Pimolsathein, 2012).

However, the increasing number of the tourist and the transforming of socio-economic activities finally may risk losing the collective unique identities and values. (Sanglimsuwan and Sanglimsuwan, 2012; Chukaew, 2014) Studying the social and cultural impacts of tourism will help to plan and set the direction of tourism to balancing between business and the common ways of life, or make the tourism enhance the ability of the communities to stand by themselves or provide the choices for the local people (Eawsriwong, 1989).

The materialized example of the impacts of tourism has been seen in Pai District, Mae Hong Sorn Province. After Pai shifted to the full-scale tourist attraction in 1997, its physical appearance had been changed rapidly; the land usage, the density of the settlements and buildings that were contrasting to the original surroundings and the overflow with the outside culture cause change in their way of life; food, costume, language, values, beliefs and tradition of the community were deteriorated (Manit, 2007). Therefore, the objective of this study was to investigate the occurrences of the natives in the central region of Thailand emigrating from their aboriginal communities from this cause.

\subsection{Literature Review}

\subsection{Cultural Heritage Conservation}

Cultural Heritage means not only the archaeological structure or buildings but also the environment and surroundings include the ecosystem. It is the mark of activities and accomplishment of human in the past, and it is among one of the significant resources that could not be reconstructed if disappeared. (Feilden and Jokileht, 1998) The attempt of Conservation of the Cultural Heritage of any kind should have a goal not only to protect the physical form of architecture and nature, but also the Cultural Heritage in the shape of the legacy in the way of life, artistic expressions, languages, customs and practices, such as the 
way to earn a living, religious customs, traditions and beliefs.

\subsection{Sustainable Development}

The concept of Sustainable Development (SD), including of Social dimension, Economic dimension, Environmental aspect is used widely. The World Tourism Organization (WTO) is one of the organizations that adopted this concept in the tourism form, as tourism could be the activity that causes damages to the environment. WTO focus on the service that harmonious with the tourism resources in each community. To reach the goal of Sustainable Tourism Development, the Earth Summit in 1992 at Rio de Janeiro, Brazil has defined Sustainable Tourism in term of "the tourism that is not harm to the environment in every form, wherever its destination is, in large group or small, both in urban or rural area" (Chittangwattana, 2005).

\subsection{Sustainable Tourism}

Sustainable Tourism is the travel with a primary objective in the Sustainable Development, by concerning the capability of the nature, community, customs, culture and the way of life in managing the tourism and focus on participating the community in tourism management (Tourism Authority of Thailand, 1996). The concept of sustainable cultural tourism has an objective to keep the balance in the developing of tourism, between the conservation of the cultural heritage and the economic growth. It is the tourism that benefits to the economic growth, not affects or causes damages to travel resources, to the cultural value of the tourism sites and the social structure of the area. The economic development of the tourism should be go along with the protection of the cultural value and the appropriate management to restrain the adverse effect to the communal way of life, culture, economic, society and politic. (Swarbrooke, 1999; Sanglimsuwan and Sanglimsuwan, 2012).

\subsection{Methodology}

This research is the qualitative research. The qualitative data for the contents analysis has been collected through the interview as well as the documentary analysis. Thus, the study divides into two parts. The first part is the analyze of the relevant research reports to find the variable of the impacts of tourism on each area. The second part is the main part which use the in-depth interview to the local people to get the actual data from the field from the six original dwellers from 3 different areas. The discussion with the informants has the specific purpose that is to learn and understand the in-depth issues for answering the research questions (Erlandson, 1993). The form of the interview is the semi-structured interview; have only board guideline questions, flexible in each context of the conversation and using the open-ended questions. The areas of study divided into three regions;

1) Amphawa Floating Market, Amphawa district, Samut Sakorn Province

2) Samchuk: 100 Years Old Market, Suphanburi Province

3) Chiang Khan old town and market, Leuy Province 


\subsection{Results and Discussion}

\subsection{The effects of tourism to the communities in Thailand}

The impacts of tourism to the community, collected from the research reports and articles could be divided into the economic effects, the social implications, and the cultural implications.

The Economic Impacts: The economic implications of tourism on the community and dwellers is that most of the income went to the trunks of great entrepreneurs, with higher competition in the community and higher cost of living for the residents. The outsourcing merchandise and products have been substituting the local products. The entrepreneurs had conflicts with the residents because they did not care to return the benefits to the community. The form of local business was change to focus on doing business with the tourist and expect the profit that caused a high competition and stress. The land value was increased and the rental rate was higher. However, the positive impact is the dwellers get benefit from the higher income, the higher rate of house rent and tourism created more opportunities to earn their living and new jobs that come along with the tourism industry.

The Social Impacts: The extended-family with a close relationship and interdependence between all members of the family is declined because the family members need to go out and do a job to serve the tourist. The tension in the community was increased from the business competition. The community was much more crowded from the increasing number of the visitors and the merchants or the business owners. The imitation of tourists' behavior and lifestyle both of the resident tourists and the foreign tourists such as entertaining themselves in a pub or any other kinds of the night-life style. In some areas, local visitors were ignored, and the foreign tourist was exploited from the wrong price. For the positive social effects, the host communities can mix with people from diverse backgrounds and cultures, and they were opened to the wider world.

The Cultural Impacts: The local traditions and culture changed or disappeared in the context of development, such as offering food to monks doing morning alms run by boat in Amphawa community or offering the sticky rice to monks in Chiang Khan community. The unique customs and traditions that practiced for a long time by the local people were changing and adapted to serve the tourists instead. The fading of the local jobs, the local costumes, and the local dialects also adverse impacts of tourism to the community. For example, in Chiang Khan the modern fashion of the tourists replaced the local costume, the local people used the official language and learned to speak English to communicate with foreign visitors.

To sum up, the emerging of tourism in the cultural heritage community caused impacts in every community but deferent level and issues, both positive and adverse effects. Tourism is the cause of change not only in a physical surrounding but has affected the economy, society, and culture. The impacts are very depended on the number of tourists and the popularity of the community; if the community is very famous and well-known, the more results is expected. 


\subsection{The in-depth impacts of tourism in each specific area}

The analysis will be divided into three areas with different impact and context.

Amphawa Floating Market is one of the most famous floating market. Both Thai and foreign tourists come to the place in large number. From the interview, after the coming of tourism, economic, social and cultural change immensely occurred to the community. The land price has been higher and most of the dwellers was pleased to sell their estate which situate the Riverside old wooden houses. From the perspective of conservationists and outsiders, these old wooden houses are the invaluable cultural heritage. The investors brought the land and destroyed the old houses to build the western style hotel in contrast to the surroundings. In another hand, the higher land price brought also a better life and more income to the dwellers. Moreover, the higher rental rate caused some dwellers to move out from the riverside old houses in the community and buy houses in the housing estate away from the community. The outsider merchants replace the original dwellers or local merchants. In social aspect, the rural and agricultural way of life was change into the tourism industry way of life. The local culture is present to the tourists' need, with the same form, but in the new content. For example, offering food to monks doing morning alms run by boat is the tradition that will be preserve for the purpose of tourists' attraction, not for the residents' appreciation.

Samchuk Market has been known as 100 Years Old Market. Most of the merchants in the market are still the local people and sell their local products; even some outsiders have come in and sold the new kind of products. Due to the higher rental rate, some people move out to the capital to find a new opportunity. The family structure has been changing with the times and from the coming of the new group of people that moved in to do their tourism business. Most original communal customs and ceremonies still continue, for example, the market blessing ceremony, and the New Year's Eve ceremony that invite anybody to eat and drink everything in the market for free at that day, because the community see the value of the tradition and everyone is willing to participate and carry on.

Chiang Khan old town and market is another community with the reputation of the cultural heritage site, but in comparison, its impacts from tourism is less than the 2 communities above. Although, there is a problem of massive land purchase by the investors and the entry of the local dwellers into tourism business sector, overall situation did not have much effects on the local culture or disrupted it. Less population moved out from the community compared to the other communities, due to the good management of the Municipality and local government that caused a city planning and a gradual change possible. The surrounding has been still a rural and agricultural countryside, but it cannot be denied that the tourism change the community into urban society. Besides the physical structure change, the modern costume, urban life style and night-life entertainment and the use of the official central Thai language instead of local dialect are among the apparent change.

\subsection{Discussion}

Base on the conceptual framework that the conservation of the cultural heritage has to cooperate in both the tangible and intangible culture (Pimolsathien, 2013), tourism should not destroy these intangible cultural heritages. Sustainable cultural tourism is the tourism that 
makes growth for economic, but not destroys the tourism resources itself and not devalues the social and cultural tourism capital of the community as well as not destroy the social structure of that area (Swarbrooke, 1999).

To accomplish in sustainable tourism management, there are 2 factors to be considered, first is the local governments or municipalities must have the power to plan, manage, and administrate their community, including the implement of local law, as well as have fully the tax authority in order to control the physical structures and to surround of the community in the big picture. The second is the participation of the communal residents that could develop the community's strength. Learning from other successful tourism managing community is a crucial lesson (Pongsakornrungsilp, 2014).

\subsection{Conclusion}

In conclusion, tourism in cultural heritage community evidently caused the economic, social and culture impacts to the host community, but both in the positive and negative way. I $f$ tourism causes a more significant change to the community, and the origin population would move out more and more. Good and effective local managements, as well as the cultural and social strength of the community, could moderate the magnitude of the negative impacts.

\section{Acknowledgement}

I am heartily thankful to my advisor, Panayu Chairatananonda, whose encouragement, guidance and support from the initial to the final level enabled me to develop an understanding of the subject. Lastly, I offer my regards and blessings to all of those who supported me in any respect during the completion of the project.

\section{References}

Chanpeng, M. and Chairatananonda, P. (2015). Reducing adverse impact guideline for tourism development in cultural tourism place, traditional community: A case study of waterfront community, Chiang khan District, Loei Province. Veridian E-Journal, Slipakorn University 8 issue 2 May - Aril 2015.

Chittangwattana, B. (1999). Sustainable Tourism Development Planning (1st ed.). Chiangmai: Chiangmai University.

Chittangwattana, B. (2005). Sustainable Tourism Development. Bangkok: Press and Design.

Chukaew, P. (2014). The Conservation of Thailand's traditional residential communities: The Field Work Experience. Bangkok: Pluspress.

Creswell, J. W. (2013). Qualitative inquiry and research design: Choosing among five 
approaches. London: SAGE Publications Ltd.

Eawsriwong, N. (1989). Cultural community and tourism. Chiangmai: Chiangmai University.

Erlandson, D. A. (1993). Doing naturalistic inquiry: A guide to methods. London: SAGE Publications Ltd.

Feilden, Sir B., \& Jokilehto, J. (1998). Management guidelines for World Cultural Heritage sites (2nd ed.). Rome: ICCROM.

Guzmán, P. C., Roders, A. P., \& Colenbrander, B. J. F. (2017). Measuring links between cultural heritage management and sustainable urban development: An overview of global monitoring tools. Cities, 60, 192-201.

Harachai P., \& Bejrananda M. (2009). The tourism capacity assessment of Sisaket for the formation of provincial sustainable tourism development policy. Report on the 8th Asia Pacific Forum for Graduate Students Research in Tourism Conference, July.

Manit, T. (2007). Impacts of Tourism Development on Local Community: A Case Study of Tambon Wiang Tai, Amphoe Pai, Changwat Mae Hong Son. Chiangmai: graduate school, Chiangmai University.

Meak-on, S. \& Bejarananda, M. (2013). Tourism Impact on Community Identity: Case of Amphawa Community. Architecture journal, KhonKhan University, 12.

Pewnim, M. (2003). Project development and the impact of tourism a case study floating market.

Pimolsathien, Y. (2013). Conservation of urban and revival of urban. Bangkok: Thammasat university.

Pimolsathein, Y. (2012). Critical Issues on The Conservation of Historic Urban Community For Thailand 9.

Pongsakornrungsilp, P. (2014). The Management of Sustainable Community-Based Tourism: The Case of Ban Kokekrai, Phang Nga Province. International Humanities, Social Sciences and arts, 7(3), 650-665.

Sanglimsuwan, K. \& Sanglimsuwan, S. (2012). Sustainable cultural heritage tourism. Executive Journal, 32.4, 139-146.

Seyanont, A. (2009). The Prevention of Deterioration and Natural Resources and Environmental Conservation of Amphawa Floating Market. University of the Thai Chamber of Commerce journal, 29(4). 
Swarbrooke, J. (1999). Sustainable Tourism Management. London: CABI.

Sudchaya, S. (2009). Urban conservation. Bangkok: Amarin printing and publishing.

Tharawan, A. \& Pewnim, M. (2014). Social - Cultural Impacts Of Tourism Management In Chiang Khan, Loei Province. Thailand Graduate research conference.

Tourism Authority of Thailand. (1996). Tourism development in a sustainable direction (2nd ed.). Bangkok.

United Nations. (2012). The future we want: Outcome document adopted. Rio +20 Conference on Sustainable Development. Rio de Janeiro meeting, June, 1-49. 